University of South Florida

DIGITAL COMMONS

Digital Commons @ University of

@ UNIVERSITY OF SOUTH FLORIDA

South Florida

$2-2008$

\title{
Middle Miocene Ice sheet Dynamics, Deep-Sea Temperatures, and Carbon Cycling: A Southern Ocean Perspective
}

Amelia E. Shevenell

University of California, Santa Barbara, ashevenell@usf.edu

James P. Kennett

University of California, Santa Barbara

David W. Lea

University of California, Santa Barbara

Follow this and additional works at: https://digitalcommons.usf.edu/msc_facpub

Part of the Life Sciences Commons

\section{Scholar Commons Citation}

Shevenell, Amelia E.; Kennett, James P.; and Lea, David W., "Middle Miocene Ice sheet Dynamics, Deep-Sea Temperatures, and Carbon Cycling: A Southern Ocean Perspective" (2008). Marine Science Faculty Publications. 585.

https://digitalcommons.usf.edu/msc_facpub/585

This Article is brought to you for free and open access by the College of Marine Science at Digital Commons @ University of South Florida. It has been accepted for inclusion in Marine Science Faculty Publications by an authorized administrator of Digital Commons @ University of South Florida. For more information, please contact digitalcommons@usf.edu. 


\title{
Middle Miocene ice sheet dynamics, deep-sea temperatures, and carbon cycling: A Southern Ocean perspective
}

\author{
Amelia E. Shevenell \\ Geological Sciences and Marine Science Institute, University of California, Santa Barbara, Santa Barbara, California \\ 93106, USA \\ Now at School of Oceanography, Box 357940, University of Washington, Seattle, Washington 98195, USA \\ (ashevenell@ocean.washington.edu)

\section{James P. Kennett and David W. Lea \\ Geological Sciences and Marine Science Institute, University of California, Santa Barbara, Santa Barbara, California 93106, USA}

[1] Relative contributions of ice volume and temperature change to the global $\sim 1 \% \delta^{18} \mathrm{O}$ increase at $\sim 14 \mathrm{Ma}$ are required for understanding feedbacks involved in this major Cenozoic climate transition. A 3-ma benthic foraminifer $\mathrm{Mg} / \mathrm{Ca}$ record of Southern Ocean temperatures across the middle Miocene climate transition reveals $\sim 2 \pm 2{ }^{\circ} \mathrm{C}$ cooling $(14.2-13.8 \mathrm{Ma})$, indicating that $\sim 70 \%$ of the increase relates to ice growth. Seawater $\delta^{18} \mathrm{O}$, calculated from $\mathrm{Mg} / \mathrm{Ca}$ and $\delta^{18} \mathrm{O}$, suggests that at $\sim 15 \mathrm{Ma}$ Antarctica's cryosphere entered an interval of apparent eccentricity-paced expansion. Glaciations increased in intensity, revealing a central role for internal climate feedbacks. Comparison of ice volume and ocean temperature records with inferred $p \mathrm{CO}_{2}$ levels indicates that middle Miocene cryosphere expansion commenced during an interval of Southern Ocean warmth and low atmospheric $p \mathrm{CO}_{2}$. The Antarctic system appears sensitive to changes in heat/moisture supply when atmospheric $p \mathrm{CO}_{2}$ was low, suggesting the importance of internal feedbacks in this climate transition.

Components: 8539 words, 4 figures.

Keywords: paleoceanography; Cenozoic climate; geochemistry; Antarctica.

Index Terms: 4924 Paleoceanography: Geochemical tracers; 4934 Paleoceanography: Insolation forcing; 4207 Oceanography: General: Arctic and Antarctic oceanography (9310, 9315).

Received 25 June 2007; Revised 26 October 2007; Accepted 7 November 2007; Published 9 February 2008.

Shevenell, A. E., J. P. Kennett, and D. W. Lea (2008), Middle Miocene ice sheet dynamics, deep-sea temperatures, and carbon cycling: A Southern Ocean perspective, Geochem. Geophys. Geosyst., 9, Q02006, doi:10.1029/2007GC001736.

\section{Introduction}

[2] A significant reorganization of Earth's climate system occurred in the middle Miocene, as evidenced by the abrupt $\sim 1 \%$ increase in global benthic foraminifer $\delta^{18} \mathrm{O}$ at $\sim 14 \mathrm{Ma}$ [Shackleton and Kennett, 1975; Miller et al., 1987; Flower and Kennett, 1994; Zachos et al., 2001]. This step-like $\delta^{18} \mathrm{O}$ increase is one of three major $\delta^{18} \mathrm{O}$ events that punctuate the long-term Cenozoic $\delta^{18} \mathrm{O}$ record and is thought to reflect some combination of Antarctic ice growth and global cooling [Shackleton 
and Kennett, 1975; Matthews and Poore, 1980; Miller et al., 1987; Prentice and Matthews, 1991; Flower and Kennett, 1994]. Support for this interpretation is found throughout the geologic record: Southern Ocean ice rafted debris is more abundant after $\sim 14$ Ma [Margolis, 1975; Kennett and Barker, 1990], large fluctuations in global sea level are inferred [Haq et al., 1987; John et al., 2004], paleobotanical and faunal change occurred [Woodruff and Savin, 1989; Flower and Kennett, 1994, and references therein], and the East Antarctic Ice Sheet expanded across the Antarctic continental margin (Ross Sea sector [Anderson, 1999; Cape Roberts Science Team, 2000]). However, because the $\delta^{18} \mathrm{O}$ of foraminiferal calcite $\left(\mathrm{CaCO}_{3}\right)$ is a function of both seawater $\delta^{18} \mathrm{O}\left(\delta^{18} \mathrm{O}_{\mathrm{sw}}\right)$ and the temperature of the waters in which the foraminifers calcify, fundamental questions remain concerning the magnitude and phasing of middle Miocene Antarctic ice growth and global cooling [Shackleton and Kennett, 1975; Flower and Kennett, 1994; Shevenell et al., 2004].

[3] Estimates of the magnitude of Antarctic ice growth and temperature change during the middle Miocene climate reorganization $(\sim 17-13 \mathrm{Ma})$ have been made using indirect methods, including low-latitude benthic/planktonic foraminifer $\delta^{18} \mathrm{O}$ covariance [Shackleton and Opdyke, 1973; Miller et al., 1991a, 1991b], sequence stratigraphy [Haq et al., 1987; Miller et al., 1987; John et al., 2004], and meridional stable isotope gradients $\left(\Delta \delta^{18} \mathrm{O}\right.$ [Wright et al., 1992]). These studies estimate that $\sim 70 \%$ of the global $\sim 1 \%$ o benthic foraminifer $\delta^{18} \mathrm{O}$ increase at $\sim 14$ Ma relates to Antarctic ice volume. Thus global deep waters are inferred to have cooled $1.5-2.5^{\circ} \mathrm{C}$ between 14.2 and $13.8 \mathrm{Ma}$ [Miller et al., 1991a, 1991b; Wright et al., 1992; Flower and Kennett, 1994; John et al., 2004]. Although indirect methods provide useful approximations of the relative contributions of ice volume and temperature to the middle Miocene $\delta^{18} \mathrm{O}$ signal, none involve a truly independent measure of either deep-water temperature or ice volume.

[4] Separation of the components of the $\delta^{18} \mathrm{O}$ signal is required to improve understanding of the processes and feedbacks involved in this dynamic climate reorganization. The recently developed $\mathrm{Mg} / \mathrm{Ca}$ paleotemperature proxy should provide an independent temperature record necessary to reveal the ice volume component of the middle Miocene $\delta^{18} \mathrm{O}$ signal. The $\mathrm{Mg} / \mathrm{Ca}$ content of foraminifer $\mathrm{CaCO}_{3}$ is a function of both seawater $\mathrm{Mg} / \mathrm{Ca}$ and calcification temperature $\left(\sim 9 \% /{ }^{\circ} \mathrm{C}\right)$ [Lea et al., 2000; Lear et al., 2000; Martin et al., 2002]. This technique is appealing because it is useful in sediments with low organic carbon content and $\mathrm{Mg} / \mathrm{Ca}$ may be measured on the same foraminifer $\mathrm{CaCO}_{3}$ as the $\delta^{18} \mathrm{O}$ [Lea et al., 2000; Lear et al., 2000]. However, the success of the $\mathrm{Mg} / \mathrm{Ca}$ paleotemperature proxy on Cenozoic timescales depends upon well-preserved foraminifer $\mathrm{CaCO}_{3}$, accurate speciesspecific temperature calibrations, and knowledge of past seawater $\mathrm{Mg} / \mathrm{Ca}$ [Lear et al., 2000; Billups and Schrag, 2002, 2003; Zachos et al., 2003; Shevenell et al., 2004]. Additionally, there is some evidence to suggest that benthic foraminfer $\mathrm{Mg} / \mathrm{Ca}$ may be influenced by changes in the carbonate ion content of seawater (Elderfield et al. [2006] and others); understanding this relationship is presently an active research topic. The results of several lowresolution middle Miocene benthic foraminifer $\mathrm{Mg} / \mathrm{Ca}$ studies agree with the indirect ice volume and temperature estimates discussed previously, suggesting the potential utility of this proxy for use on Cenozoic timescales [Lear et al., 2000; Billups and Schrag, 2002]. A 0.6-0.7\%o increase in $\delta^{18} \mathrm{O}_{\mathrm{sw}}$ and a $2.5-3^{\circ} \mathrm{C}$ cooling of global deep waters have been inferred using paired benthic foraminifer $\mathrm{Mg} / \mathrm{Ca}$ and $\delta^{18} \mathrm{O}$ records [Lear et al., 2000; Billups and Schrag, 2002, 2003]. However, the resolution of these studies is presently too low to assess the magnitude and phasing of ice growth and cooling on orbital timescales.

[5] Here we use the $\mathrm{Mg} / \mathrm{Ca}$ paleotemperature proxy to gain new high-resolution insight into both the relative contributions of Antarctic ice volume and temperature to the $\sim 14 \mathrm{Ma} \delta^{18} \mathrm{O}$ increase as well as the phasing of ice growth and cooling. We present an orbital scale 3-Ma (16.5-13.5 Ma) time series of $\mathrm{Mg} / \mathrm{Ca}$-derived bottom water temperatures (BWTs) from the South Tasman Rise (STR), Southwest Pacific sector of the Southern Ocean (Figure 1). We then integrate benthic foraminifer $\mathrm{Mg} / \mathrm{Ca}$ and $\delta^{18} \mathrm{O}$ records from ODP Site 1171 to gain insight into the development of the Antarctic ice sheet during the middle Miocene climate transition.

\section{Setting}

[6] ODP Site $1171\left(48^{\circ} 30^{\prime} \mathrm{S}, 149^{\circ} 06.69^{\prime} \mathrm{E} ; 2150 \mathrm{~m}\right.$ [Exon et al., 2001]) was drilled on the southern tip of the South Tasman Rise, which continued to move northward after the separation of Australia and Antarctica in the latest Eocene (Figure 1 [Exon et al., 2001]). In the middle Miocene, the South Tasman Rise was situated at a paleolatitude of $55^{\circ} \mathrm{S}$ [Lawver et al., 1992] and the site is estimated to have been at a paleodepth of $1600 \mathrm{~m}$ [Sclater et al., 


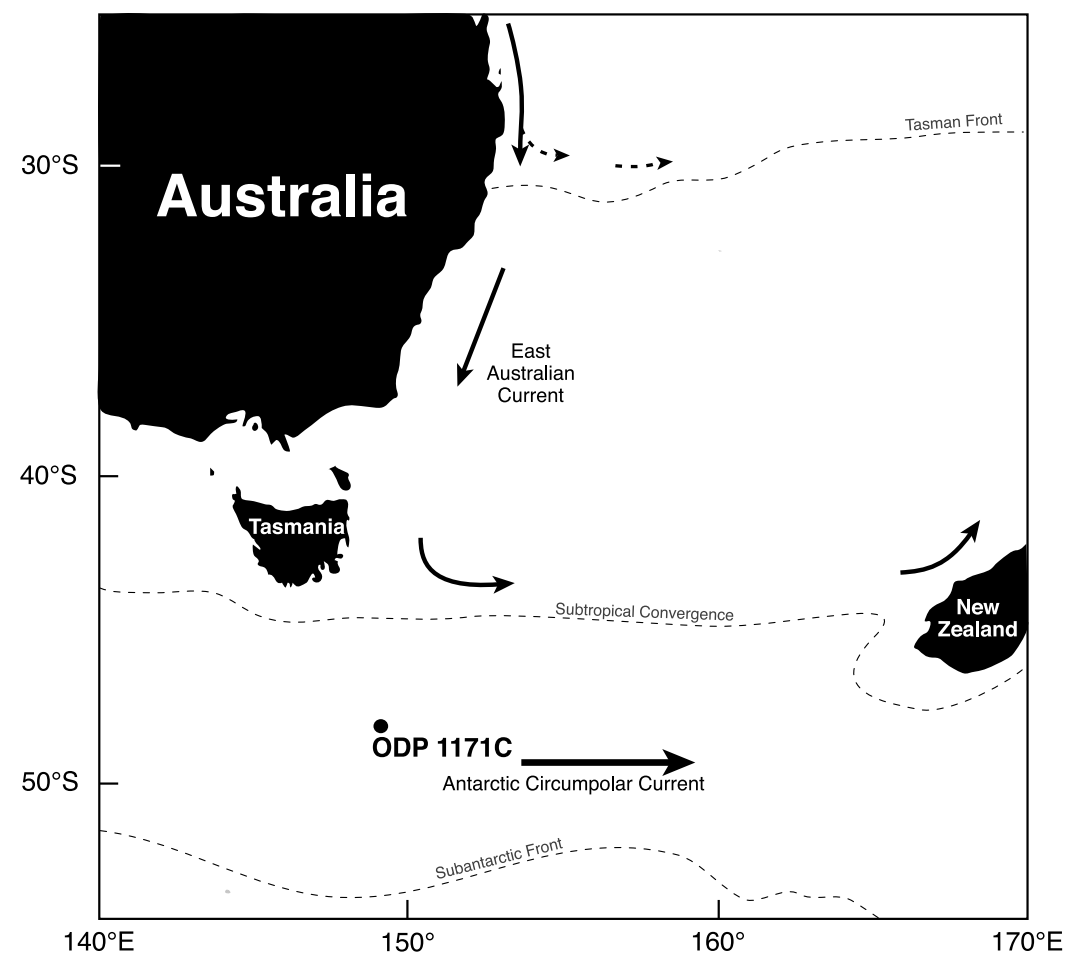

Figure 1. Ocean Drilling Program (ODP) Site 1171 is situated on the South Tasman Rise (STR) at the intersection of the southward flowing East Australian Current (EAC) and the eastward flowing Antarctic Circumpolar Current (ACC), one of three locations where heat is introduced to the Southern Ocean [Exon et al., 2001]. In the middle Miocene, the STR was situated at $\sim 55^{\circ} \mathrm{S}, 5-7^{\circ}$ south of its present location [Lawver et al., 1992]. The backtracked middle Miocene paleodepth of Site 1171 is $1600 \mathrm{~m}$ [Sclater et al., 1985].

1985]. The site is proximal to the confluence of the East Australian Current and the Antarctic Circumpolar Current and was likely bathed by both Southern Component Water and Southern Component Intermediate Water during the Miocene (Figure 1 [Shevenell and Kennett, 2004]).

\section{Materials/Methods}

[7] Oligocene to Quaternary sediments at Site 1171 are predominantly nannofossil to foram-bearing nannofossil chalks and oozes $\left(\sim 94 \% \mathrm{CaCO}_{3}\right)$, suggesting that the STR has been located above the Southwest Pacific/Southern Ocean lysocline since the early Oligocene [Exon et al., 2001]. The middle Miocene sequence (150-220 mbsf) analyzed in this study is predominantly a nannofossil ooze; the ooze/chalk boundary is located at $\sim 270$ mbsf, below the sequence discussed [Exon et al., 2001]. On the basis of our own observations, there is little visual evidence of dissolution or other diagenetic processes in the middle Miocene sequence, with the possible exception of the 180-190 mbsf interval, which exhibits a reduced number of benthic foraminifers and no change in planktonic foraminifer fragmentation [Shevenell, 2004; A. E. Shevenell and J. P. Kennett, manuscript in preparation, 2008]. Our observations suggest that multiple planktonic foraminifer species are well preserved through out, including some dissolution susceptible species (e.g., Orbulina sp.) [Shevenell, 2004]. Furthermore, interspecific benthic and planktonic $\delta^{18} \mathrm{O}$ and $\delta^{13} \mathrm{C}$ offsets [Shevenell, 2004], and the quality of the planktonic $\mathrm{Mg} / \mathrm{Ca}$ record [Shevenell et al., 2004] suggest an absence of widespread postdepositional alteration of Hole $1171 \mathrm{C}$ sediments.

[8] Middle Miocene age control is constrained by 19 magneto-, bio-, and stable isotope datums (Exon et al. [2001]; see Shevenell and Kennett [2004] for details) between 11.1 and $16.7 \mathrm{Ma}$. For this contribution, we have updated the nine datums used in the Shevenell and Kennett [2004] Site 1171 age model between 13.3 and $16 \mathrm{Ma}$ to reflect the new astronomically tuned ATNTS2004 age model of Lourens et al. [2004]. Our revised linearly interpolated age model between 13.3 and $16 \mathrm{Ma}$ is similar to the revised Site 1171 age model of Holbourn et al. [2005] between 13.7 and 14.3 Ma. Differences between our revised age model (this contribution) 
and the astronomically tuned age model of lower latitude Sites 1146 and 1237 of Holbourn et al. [2007] are slightly greater $(200-300 \mathrm{Ka})$ around $\sim 15$ Ma but do not impact our interpretations of the benthic $\mathrm{Mg} / \mathrm{Ca}$ data or the conclusions of this contribution. We have chosen to plot the Site 1171 data using a revised linear interpolation through the 9 age control points identified in the Site 1171 record between 13.3 and $16 \mathrm{Ma}$ (1) because this model extends beyond 14.3 Ma and has not been tuned to the $\delta^{18} \mathrm{O}$ of Sites 1146 and 1237 [Holbourn et al., 2005, 2007]:

$y=14.148 x-32.91\left(r^{2}=0.9993\right)$ from 113 and $205 \mathrm{mbsf}$

where $\mathrm{y}$ is depth and $\mathrm{x}$ is age. Thus the average sedimentation rate between 11.1 and $16.7 \mathrm{Ma}$ is 14.148 m/Ma [Shevenell and Kennett, 2004].

[9] Raw sediment was washed over a $63-\mu \mathrm{m}$ sieve, oven dried at $50^{\circ} \mathrm{C}$, and the residual $>63-\mu \mathrm{m}$ sample split. Both stable isotope and trace element analyses were conducted at UCSB; the details of the stable isotope analyses may be found in the work of Shevenell and Kennett [2004]. The $\mathrm{Mg} / \mathrm{Ca}$ data were generated from the same samples but not from the same foraminifers as the $\delta^{18} \mathrm{O}$ data [Shevenell et al., 2004]. For each of the 211 trace metal analyses, 5 to 16 benthic foraminifer, Cibicidoides mundulus, individuals were picked from the 250-350 $\mu \mathrm{m}$ fraction. In 24 samples, low C. mundulus abundance limited analysis to $3-$ 4 individuals. Foraminifer shells were weighed, crushed, and cleaned following the protocol developed for foraminiferal trace metal analysis, which focuses on removing clays, organic matter, and metal oxides [Boyle and Keigwin, 1985; Lea and Boyle, 1993]. Dissolved samples were analyzed by the isotope dilution/internal standard method described by Lea and Martin [1996] using a Thermo Finnigan Element2 sector ICP-MS.

[10] Analytical reproducibility over the course of this study ( $\sim 18$ months) was determined using consistency standards with similar concentrations and $\mathrm{Mg} / \mathrm{Ca}$ ratios to dissolved benthic foraminifer solutions. Thus the long-term analytical precision (\% r.s.d.) was $\pm 0.7 \%(1 \sigma)$. Less than $5 \%$ of the individual analyses were rejected as outliers. Cleaned samples with $<10 \%$ recovery yielded insufficient signal for reliable $\mathrm{Mg} / \mathrm{Ca}$ determination and were excluded from the data set. Replicate analyses $(\mathrm{df}=65)$ were conducted on $30 \%$ of the Site 1171 samples during the course of this study.
Precision of the $\mathrm{Mg} / \mathrm{Ca}$ data is estimated from the pooled standard deviation of replicate analyses is $\pm 9.8 \%$ and is higher than that of both Miocene planktonic $\mathrm{Mg} / \mathrm{Ca}$ from Site 1171 [Shevenell et al., 2004] and Quaternary benthic $\mathrm{Mg} / \mathrm{Ca}$ studies [Martin et al., 2002]. This discrepancy likely relates to the long time interval represented by each sample $(11-17 \mathrm{ka})$ coupled with the relatively low $C$. mundulus abundance in each sample.

\section{Results}

\subsection{Stable Isotope Record}

[11] The benthic foraminifer $\delta^{18} \mathrm{O}$ record from Site 1171 (see Shevenell and Kennett [2004] for details) consists of $758 \delta^{18} \mathrm{O}$ analyses (20\% are duplicates) and is characteristic of the majority of middle Miocene deep-sea $\delta^{18} \mathrm{O}$ records [e.g., Woodruff and Savin, 1991; Flower and Kennett, 1994]. Oxygen isotope values are generally more negative between 16.5 and 13.9 Ma (average: 2.1\%o) and more positive (average: $2.8 \%$ ) after $13.8 \mathrm{Ma}$, with a total range of $1.9 \%$ (Figure 2). Values are generally most negative between 16.5 and $14.6 \mathrm{Ma}$, with the most negative $\delta^{18} \mathrm{O}$ values observed between 16.5 and 16.2 Ma and an interval of more positive $\delta^{18} \mathrm{O}$ centered at $\sim 16 \mathrm{Ma}$. After $15 \mathrm{Ma}$, two intervals of more positive $\delta^{18} \mathrm{O} \sim 400 \mathrm{ka}$ long are centered at 14.8 and $14.4 \mathrm{Ma}$. The $\delta^{18} \mathrm{O}$ record exhibits the most variability between 14.6 and 14.0 Ma and $\delta^{18} \mathrm{O}$ values generally more negative and less variable between 14.0 and 13.9 Ma. Two intervals of more positive $\delta^{18} \mathrm{O}$ are centered at 14.0 and 13.9 Ma. The well-known middle Miocene $\delta^{18} \mathrm{O}$ increase is evident in the Site $1171 \delta^{18} \mathrm{O}$ record and displays a $0.75 \%$ d $\mathrm{d}^{18} \mathrm{O}$ increase between 13.9 and $13.8 \mathrm{Ma}$, equivalent to the Mi-3 event of Miller et al. [1991a]. The most positive $\delta^{18} \mathrm{O}$ values of the record (average: $2.8 \% 0$ ) occur between 13.8 and $13.7 \mathrm{Ma}$. The $\delta^{18} \mathrm{O}$ values decrease $\sim 0.2 \%$ o (average: $2.6 \%$ o) and remain relatively stable after $13.7 \mathrm{Ma}$ [Shevenell and Kennett, 2004].

\section{2. $\mathrm{Mg} / \mathrm{Ca}$ Record}

[12] At first glance it is clear that unlike the Site 1171 planktonic foraminifer $\mathrm{Mg} / \mathrm{Ca}$ record [Shevenell et al., 2004], the benthic foraminifer $\mathrm{Mg} / \mathrm{Ca}$ record bears little resemblance to the benthic foraminifer $\delta^{18} \mathrm{O}$ record (Figure 3 [Shevenell and Kennett, 2004]). Hole $1171 \mathrm{C}$ benthic $\mathrm{Mg} / \mathrm{Ca}$ values exhibit low variability through the middle Miocene and range between 1.21 and $2.10 \mathrm{mmol} / \mathrm{mol}$ with an 


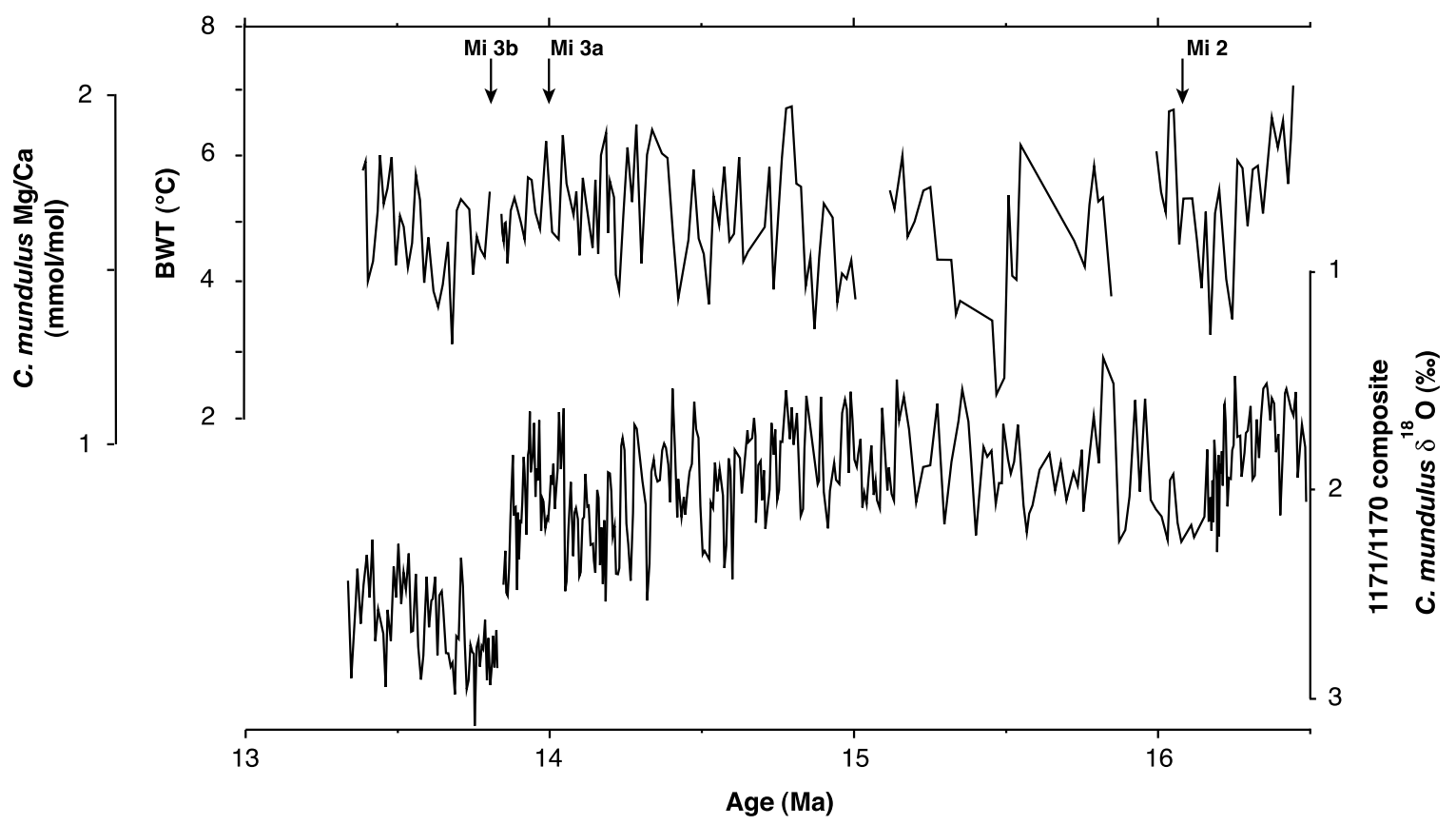

Figure 2. C. mundulus (top) $\mathrm{Mg} / \mathrm{Ca}$ and (bottom) $\delta^{18} \mathrm{O}$ from ODP Hole $1171 \mathrm{C}\left(48^{\circ} 30^{\prime} \mathrm{S}, 149^{\circ} 06.69^{\prime} \mathrm{E} ; 2150 \mathrm{~m}\right.$ ) plotted versus age (a detailed discussion of the age model may be found in the text). Data were generated at $20 \mathrm{~cm}$ intervals $(\mathrm{Mg} / \mathrm{Ca})$ and at $10 \mathrm{~cm}$ intervals $\left(\delta^{18} \mathrm{O}\right.$ [Shevenell and Kennett, 2004]) from 150 to 205 meters below sea floor (mbsf). Each $\mathrm{Mg} / \mathrm{Ca}$ data point represents an average of one to six analyses. Analytical reproducibility over the 18 -month study, determined using consistency standards, is estimated at $\pm 0.7 \%(1 \sigma)$. Replicate analyses $(\mathrm{df}=65)$ were conducted on $\sim 30 \%$ of the samples. Precision of $\mathrm{Mg} / \mathrm{Ca}$ data, estimated from the pooled standard deviation of the replicates, is $\pm 9.8 \%$. Mi events of Miller et al. [1991b] are identified.

average of $1.66 \mathrm{mmol} / \mathrm{mol} \pm 0.165$ (1 s.d.; $13.2-$ $16.4 \mathrm{Ma})$.

[13] The Hole $1171 \mathrm{C}$ benthic $\mathrm{Mg} / \mathrm{Ca}$ record exhibits a long period $(\sim 2 \mathrm{Ma})$ oscillation superimposed on a slight trend toward lower values up-section (Figure 3). Three intervals of higher $\mathrm{Mg} / \mathrm{Ca}$ are evident at $\sim 16.3 \mathrm{Ma}$ (average: $1.81 \mathrm{mmol} / \mathrm{mol}$ ), $14.3 \mathrm{Ma}(1.73 \mathrm{mmol} / \mathrm{mol})$, and $\sim 13.4 \mathrm{Ma}(1.68$ $\mathrm{mmol} / \mathrm{mol}$ ); all correspond with intervals of more positive $\delta^{18} \mathrm{O}$ (Figure 3 ). In contrast to the stepwise structure of the benthic $\delta^{18} \mathrm{O}$ (Figure 2 [Shevenell and Kennett, 2004]) and planktonic $\mathrm{Mg} / \mathrm{Ca}$-derived SST [Shevenell et al., 2004] records (Figure 4) across the middle Miocene climate transition ( $\sim 14 \mathrm{Ma}$ ), the C. mundulus $\mathrm{Mg} / \mathrm{Ca}$ record exhibits reduced variability and a gradual $\sim 0.36 \mathrm{mmol} / \mathrm{mol}$ decrease (Figures 1 and 3). A reduced sampling density related to low $C$. mundulus abundance might give rise to the pronounced variability between 15.3 and 16.0 Ma (Figure 3); thus we focus our discussions and interpretations to the 15.3 to 13.3 Ma interval.

[14] To assess the influence of postdepositional alteration on the Site 1171 benthic foraminifer
$\mathrm{Mg} / \mathrm{Ca}$ record, a paired $\mathrm{Sr} / \mathrm{Ca}$ record was generated and no similarities exist between the records [Shevenell, 2004]. Furthermore, a comparison of $\mathrm{Mg} / \mathrm{Ca}$ with elemental ratios of $\mathrm{Fe} / \mathrm{Ca}, \mathrm{Al} / \mathrm{Ca}$, and $\mathrm{Mn} / \mathrm{Ca}$ indicates that no significant $\left(\mathrm{R}^{2}=<0.1\right)$ correlation exists between the records and suggests that the $\mathrm{Mg} / \mathrm{Ca}$ record is not influenced by the presences of clays or by the foraminifer cleaning process [Boyle and Keigwin, 1985].

\section{Discussion}

\subsection{Mg-Temperature Record}

[15] Bottom water temperatures were estimated from the C. mundulus $\mathrm{Mg} / \mathrm{Ca}$ data (Figure 3) using the C. mundulus-specific Mg-temperature calibration of Lear et al. [2003]:

$$
\mathrm{Mg} / \mathrm{Ca}=0.9 \mathrm{e}^{.11 \mathrm{BWT}}
$$

Assuming a minimal change in seawater $\mathrm{Mg} / \mathrm{Ca}$ from the Miocene to present [Wilkinson and Algeo, 1989; Rowley, 2002], BWT estimates should be accurate to within $\pm 1^{\circ} \mathrm{C}(2 \sigma$; Lear et al. [2003]). 


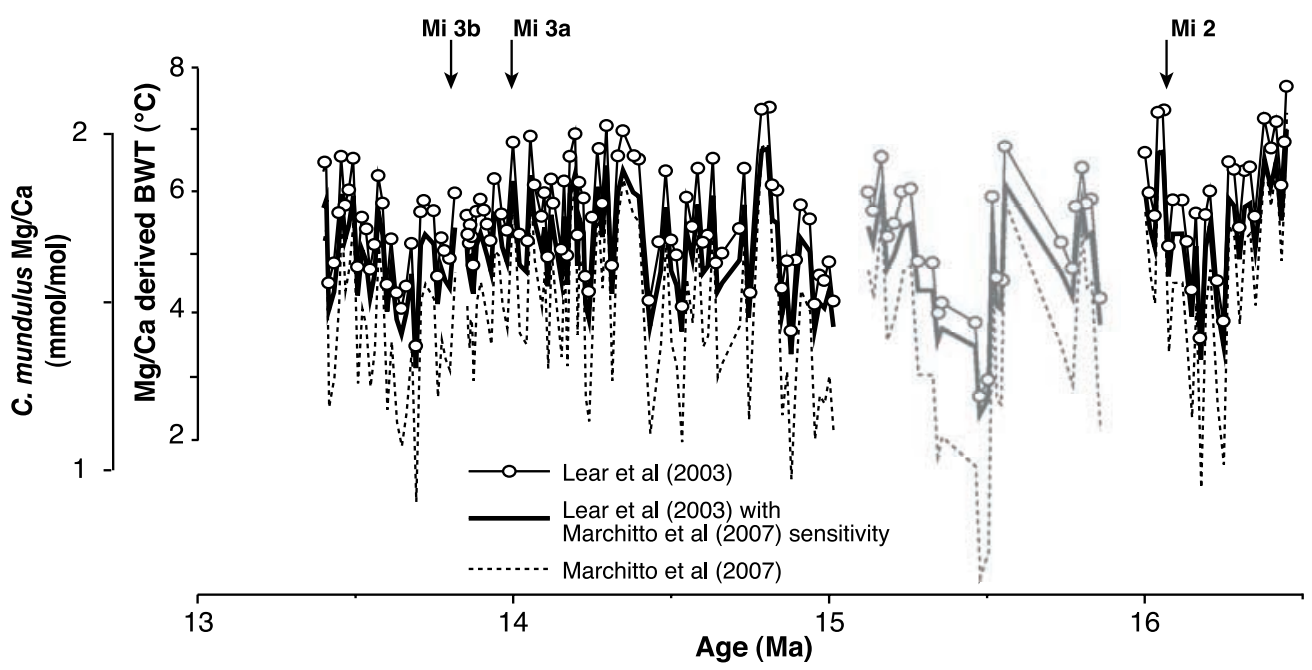

Figure 3. C. mundulus $\mathrm{Mg} / \mathrm{Ca}$-derived bottom water temperature (BWT) records versus age from ODP Hole 1171C. Mi events of Miller et al. [1991b] are identified. The three $\mathrm{Mg} / \mathrm{Ca}$-derived BWT curves represent the $\mathrm{Mg} / \mathrm{Ca}$ data converted to BWT using three different calibrations: The solid line with the open circles is temperature curve based on the calibration of Lear et al. [2003], the dotted line is the calibration of Marchitto et al. [2007], and the bold black line is the calibration of Lear et al. [2003] with the temperature sensitivity of Marchitto et al. [2007]. As discussed in the text, the differences observed between the Lear et al. [2003] and Lear and Marchitto equation are within the overall uncertainty of the $\mathrm{Mg} / \mathrm{Ca}$ calibrations and our conclusions are not significantly altered by our choice of equation.

[16] Unlike the $\mathrm{Mg} / \mathrm{Ca}$ of planktonic foraminifera, the uptake of $\mathrm{Mg} / \mathrm{Ca}$ into benthic foraminifera remains poorly understood. As a result, there is an ongoing debate in the paleoceanographic community as to whether the relationship between temperature and $\mathrm{Mg} / \mathrm{Ca}$ in benthic foraminifer is exponential or linear (Lear et al. [2002, 2003], Lea [2004], Marchitto et al. [2007], and others). We chose the Lear et al. [2003] equation to convert Site $1171 \mathrm{Mg} / \mathrm{Ca}$ to BWT because our record is exclusively derived from $C$. mundulus and because of the definite offset between $C$. mundulus and $C$. wullerstorfi observed in multispecies records [Lear et al., 2003]. Lear et al. [2003] revised their original core-top Cibicidoides calibration [Lear et $a l ., 2002]$ to obtain a species specific $C$. mundulus equation by assuming that the two species have a similar temperature sensitivity but a different preexponential constant.

[17] More recently, a core-top calibration for $C$. pachyderma (or C. mundulus) from the Little Bahamas Bank was generated by Marchitto et al. [2007], which suggests a strong linear relationship between $\mathrm{Mg} / \mathrm{Ca}$ and BWT, with a sensitivity of $0.12 \mathrm{mmol} / \mathrm{mol} \mathrm{Mg} / \mathrm{Ca}$ per ${ }^{\circ} \mathrm{C}$ :

$$
\mathrm{Mg} / \mathrm{Ca}=0.116 \mathrm{~T}+1.20
$$

The standard error of the equation is $2.4^{\circ} \mathrm{C}$. Marchitto et al. [2007] favor a linear fit to the core top data because an exponential curve exaggerates the temperatures at the cold extreme of the calibration.

[18] In order to illustrate the effect of using different calibrations on our Site 1171 middle Miocene C. mundulus $\mathrm{Mg} / \mathrm{Ca}$ record, we have plotted the results of three different equations in Figure 2: The solid line with open circles uses the exponential calibration Lear et al. [2003] and the dashed line employs the linear calibration of Marchitto et al. [2007]. We have also plotted the data using the exponential equation of Lear et al. [2003] with the temperature sensitivity of the Marchitto et al. [2007] equation (heavy black line; standard error of $\pm 1.7^{\circ} \mathrm{C}$ ); the Marchitto et al. [2007] sensitivity was substituted into the Lear et al. [2003] equation to reflect the likelihood that the temperature sensitivity of $C$. mundulus (C. pachyderma) is species specific. Furthermore, we argue that at the cold end of the calibration, the slopes of the linear and exponential equations are essentially identical:

$$
\mathrm{Mg} / \mathrm{Ca}=0.9 \mathrm{e}^{0.12 \mathrm{BWT}}
$$

Temperatures derived from the Lear et al. [2003] equation are the warmest of the three equations. The temperatures estimated from hybrid Lear- 


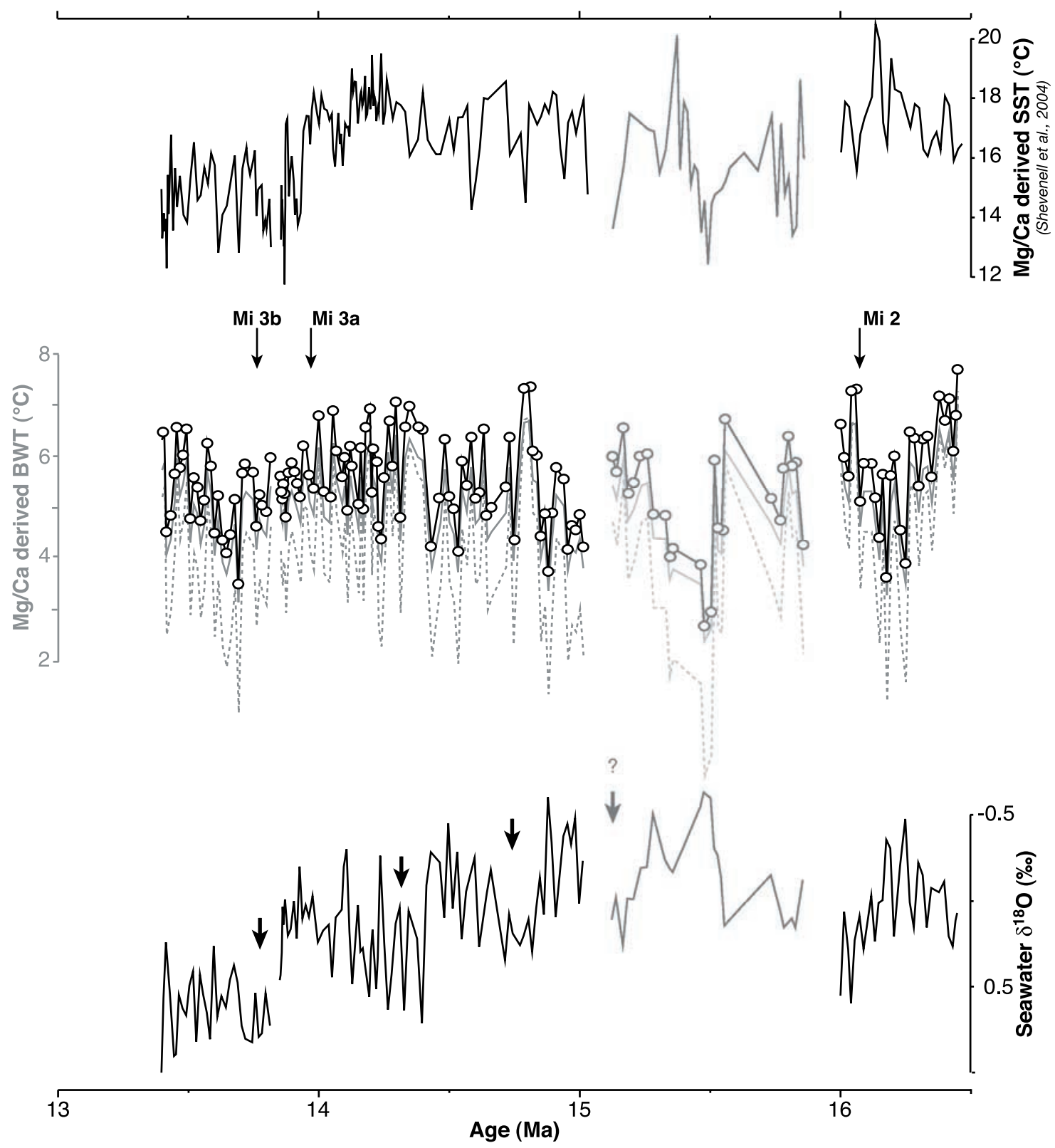

Figure 4. Southern Ocean paleoclimate records from ODP Hole $1171 \mathrm{C}\left(48^{\circ} 30^{\prime} \mathrm{S}, 149^{\circ} 06.69^{\prime} \mathrm{E} ; 2150 \mathrm{~m}\right)$ versus age (see text for age model details). Interpretations focus on the 15.3-13.3 Ma interval (black). Mi events of Miller et al. [1991b] are identified. (bottom) Seawater $\delta^{18} \mathrm{O}\left(\delta^{18} \mathrm{O}_{\text {sw }}\right)$ is calculated using the $\delta^{18} \mathrm{O}$-temperature relationship of Lynch-Stieglitz et al. [1999] from C. mundulus $\delta^{18} \mathrm{O}$ [Shevenell and Kennett, 2004] and Mg/Ca-derived BWTs [Lear et al., 2003]. The record is interpreted to reflect changes in global ice volume during the middle Miocene climate transition. Arrows indicate glaciations that recur every $\sim 400 \mathrm{ka}$ between $\sim 15$ and $14 \mathrm{Ma}$. Also shown is (middle) $\mathrm{Mg} / \mathrm{Ca}$-derived bottom water temperatures (BWTs) [Lear et al., 2003] from ODP Hole 1171C and (top) G. bulloides $\mathrm{Mg} / \mathrm{Ca}$-derived sea surface temperatures (SSTs) from ODP Hole 1171C [Shevenell et al., 2004] plotted on the age model discussed in this contribution.

Marchitto equation are slightly lower than the Lear et al. [2003] temperatures, but within the error of the Lear et al. [2003] equation. The Marchitto et al. [2007] equation yields significantly cooler temperatures, which may reflect the lack of data at the cool $\left(<5^{\circ} \mathrm{C}\right)$ end of the calibration [Lear et al., 2003;
Marchitto et al., 2007]. Furthermore, because the standard error of the Lear et al. [2003] equation is $1.0^{\circ} \mathrm{C}$ and the offset between the temperatures estimated from equation (1) and equation (3) are within error of the Lear et al. [2003] calibration, we have chosen to employ this calibration. 
[19] Using the published equation of Lear et al. [2003], we estimate that the Middle Miocene BWTs at Hole 1171C oscillated around $5.3 \pm$ $1.0^{\circ} \mathrm{C}$ (Figure 3), which is within the range of existing low-resolution Cenozoic benthic $\mathrm{Mg} / \mathrm{Ca}$ records $\left(4-8^{\circ} \mathrm{C}\right.$ [Lear et al., 2000; Billups and Schrag, 2002]). However, Site 1171 BWTs are routinely cooler than $\mathrm{Mg} / \mathrm{Ca}$ records generated at lower latitude sites, a finding consistent with the South Tasman Rise's geography and oceanographic setting [Lear et al., 2000; Billups and Schrag, 2002]. Three intervals of relatively warm BWTs exist in the Site 1171 record, including those at $16.4-16.2 \mathrm{Ma}\left(6.3 \pm 0.3^{\circ} \mathrm{C}\right), 14.5-14.1 \mathrm{Ma}(5.6 \pm$ $1.0^{\circ} \mathrm{C}$ ), and $13.5-13.3 \mathrm{Ma}\left(5.7 \pm 0.7^{\circ} \mathrm{C}\right)$ (Figure 3). Two of these warm intervals occurred during the Miocene Climatic Optimum (17-14 Ma [Flower and Kennett, 1994, and references therein]) and the third at $\sim 13.5 \mathrm{Ma}$ following the middle Miocene $\delta^{18} \mathrm{O}$ increase; warming of regional surface water temperatures [Shevenell et al., 2004] and Southwest Pacific $\left(26^{\circ} \mathrm{S}\right)$ benthic foraminifer $\mathrm{d}^{18} \mathrm{O}$ records [Flower and Kennett, 1994] has also been inferred at this time (Figure 3). Cooler BWTs observed at $\sim 16 \mathrm{Ma}\left(4.7 \pm 1.0^{\circ} \mathrm{C}\right)$ and $13.6 \mathrm{Ma}$ $\left(4.6 \pm 0.7^{\circ} \mathrm{C}\right)$ correspond with intervals of more positive $\delta^{18} \mathrm{O}$ (glacial events $\mathrm{Mi}-2$ and $\mathrm{Mi}-3$ of Miller et al. [1991a]) (Figure 3). Across the middle Miocene $\mathrm{d}^{18} \mathrm{O}$ increase $(14.2-13.8 \mathrm{Ma})$, BWTs at Site 1171 cooled $\sim 2^{\circ} \mathrm{C} \pm 1.5^{\circ} \mathrm{C}\left(\sim 6^{\circ}\right.$ to $\left.4^{\circ} \mathrm{C}\right)$ (Figure 3), which is similar to cooling estimated using indirect methods [Miller et al., 1991a; Wright et al., 1992; Flower and Kennett, 1994; John et al., 2004].

\subsubsection{Accounting for Temporal Seawater $\mathrm{Mg} / \mathrm{Ca}$ Variability}

[20] The largest uncertainty in estimating Cenozoic paleotemperatures using $\mathrm{Mg} / \mathrm{Ca}$ relates to temporal variations in seawater $\mathrm{Mg} / \mathrm{Ca}$ [Lear et al., 2000; Billups and Schrag, 2002]. Changes in $\mathrm{CaCO}_{3}$ sedimentation, dolomite cycling, hydrothermal activity, and/or the hydrologic cycle could alter seawater $\mathrm{Mg} / \mathrm{Ca}$ [Wilkinson and Alego, 1989; Stanley and Hardie, 1998; Lear et al., 2000; Billups and Schrag, 2002]. However, the long residence times of oceanic $\mathrm{Mg}^{2+}(13 \mathrm{Ma})$ and $\mathrm{Ca}^{2+}(1 \mathrm{Ma})$ [Broecker and Peng, 1982] indicate that, while the absolute values of BWTs may be affected by changing seawater $\mathrm{Mg} / \mathrm{Ca}$, the magnitude of temperature change across rapid $(<1 \mathrm{Ma})$ climate transitions should remain unchanged. Furthermore, if the seawater $\mathrm{Mg} / \mathrm{Ca}$ ratio were driven purely by changes in oceanic $\mathrm{Ca}$ cycling, then the ratio of $\mathrm{Sr} / \mathrm{Ca}$ in seawater should exhibit similar changes to that of $\mathrm{Mg} / \mathrm{Ca}$. The Site 1171 benthic foraminifer $\mathrm{Sr} / \mathrm{Ca}$ record shows no similarity to that of the $\mathrm{Mg} / \mathrm{Ca}$ [Lear et al., 2003] record and no systematic longterm trend. Thus, we assume that the long-term trends observed in the record are not related to changes in oceanic $\mathrm{Ca}$ cycling.

[21] To assess the uncertainty in the absolute values of our BWT record related to temporal seawater $\mathrm{Mg} / \mathrm{Ca}$ variations [Wilkinson and Alego, 1989; Stanley and Hardie, 1998], we modified the Lear et al. [2003] calibration equation following Lear et al. [2000]:

$\mathrm{BWT}=\ln \left(\mathrm{Mg} / \mathrm{Ca}_{\mathrm{M}} /\left(0.9 *\left(\mathrm{Mg} / \mathrm{Ca}_{\mathrm{SWM}} / \mathrm{Mg} / \mathrm{Ca}_{\mathrm{SWP}}\right)\right)\right) / 0.11$

Where $\mathrm{Mg} / \mathrm{Ca}_{\mathrm{M}}$ refers to measured $C$. mundulus $\mathrm{Mg} / \mathrm{Ca}$ (this study), $\mathrm{Mg} / \mathrm{Ca}_{\mathrm{SwM}}$ to the modeled $\mathrm{Mg} / \mathrm{Ca}$ of seawater at $\sim 14 \mathrm{Ma}(4.2 \mathrm{mmol} / \mathrm{mol}$ [Wilkinson and Algeo, 1989]), and $\mathrm{Mg} / \mathrm{Ca}$ SwP to the $\mathrm{Mg} / \mathrm{Ca}$ of present day seawater $(5.1 \mathrm{mmol} / \mathrm{mol}$ [Broecker and Peng, 1982; Stanley and Hardie, 1998]). BWT estimates derived from equation (4) are $1.8^{\circ} \mathrm{C}$ warmer than those from equation (1) [Lear et al., 2003]. Taking into account uncertainty related to temporal seawater $\mathrm{Mg} / \mathrm{Ca}$ variations and the calibration, we estimate the absolute uncertainty in Miocene BWT estimates at $\pm 1-3^{\circ} \mathrm{C}$. Because the uncertainty related to the changing ratio of $\mathrm{Mg}$ to $\mathrm{Ca}$ in seawater is within the error of the Lear et al. [2003] calibration, our discussions will focus on the temperature record derived from that equation, not equation (4). Owing to the long residence times of $\mathrm{Mg} / \mathrm{Ca}$ in the ocean, our data will not be affected on timescales of $<1 \mathrm{Ma}$. Furthermore, on longer timescales it is unlikely that the shape of the middle Miocene curve will change with a shift in the seawater $\mathrm{Mg} / \mathrm{Ca}$, but rather the absolute values will be influenced by $\pm 1-3^{\circ} \mathrm{C}$.

\subsubsection{Middle Miocene Benthic Foraminifer Mg Temperatures ( 14 Ma)}

[22] The middle Miocene $\delta^{18} \mathrm{O}$ increase at $\sim 14 \mathrm{Ma}$ is one of the three major $\delta^{18} \mathrm{O}$ increases of the Cenozoic. At Site 1171 , a $\delta^{18} \mathrm{O}$ increase of $1.2 \%$ occurs between 14.1 and 13.7 Ma. Across the same time interval, C. mundulus $\mathrm{Mg}$-temperatures cool $\sim 2 \pm 2^{\circ} \mathrm{C}$ from $\sim 6$ to $4^{\circ} \mathrm{C}$, suggesting that roughly $0.75 \%$ o $(\sim 65 \%)$ of the $1.2 \%$ o $\delta^{18} \mathrm{O}$ increase across the middle Miocene climate transition relates to global ice volume [O'Neil et al., 1969]. Thus the Site 1171 benthic $\mathrm{Mg} / \mathrm{Ca}$ record suggests no sig- 
nificant or permanent cooling following the middle Miocene climate step. Interestingly, the cooling immediately follows the relatively warm temperatures of the Miocene Climatic Optimum ( 15$14 \mathrm{Ma}$ ) and is similar in magnitude and range to bottom water temperatures observed in the lower resolution benthic foraminifer $\mathrm{Mg} / \mathrm{Ca}$ records of both Lear et al. [2000] and Billups and Schrag [2002], despite different Mg-temperature relationships used in each of the studies.

[23] $\mathrm{A} \sim 2^{\circ} \mathrm{C}$ warming trend $(13.7$ to $13.5 \mathrm{Ma})$ immediately follows the middle Miocene cooling and $\delta^{18} \mathrm{O}$ increase. Despite the uncertainties presently associated with the benthic Mg-temperature relationship, there is some evidence to suggest that the observed pattern of temperature change across the Middle Miocene $\delta^{18} \mathrm{O}$ increase is robust. A similar pattern of warming is observed following the major Cenozoic $\delta^{18} \mathrm{O}$ excursions across the Eocene/Oligocene and Oligocene/Miocene boundaries [Lear et al., 2004]. These authors propose a scenario in which warming after the major Eocene/ Oligocene (Oi-1) and early Miocene (Mi-1) Antarctic glaciations is thought to reflect a negative feedback of the climate system related to the reduction of global chemical weathering rates due to extensive continental glaciation. This reduction in weathering is thought to result in an increase in atmospheric $p \mathrm{CO}_{2}$ and a partial melting of Antarctic ice sheets, referred to by Lear et al. [2004] as the "missing sink" mechanism, which is consistent with the evidence from both the middle Miocene global benthic foraminifer $\delta^{13} \mathrm{C}$ record and proxy atmospheric $p \mathrm{CO}_{2}$ records [Pagani et al., 1999]. Carbon isotope records from Site 1171, which exhibit the global benthic foraminifer $\delta^{13} \mathrm{C}$ signal, indicate a rise in benthic foraminifer $\delta^{13} \mathrm{C}$ immediately following the major $\delta^{18} \mathrm{O}$ increase that is associated with the final orbitally paced global carbon maximum events (CM6) of the Monterey $\delta^{13} \mathrm{C}$ excursion [Vincent and Berger, 1985; Woodruff and Savin, 1991] and an increase in atmospheric $p \mathrm{CO}_{2}$ as inferred from the $\delta^{13} \mathrm{C}$ of alkenones preserved in southwest Pacific sediments [Pagani et al., 1999]. Support for reduced Antarctic ice volume at this time comes from both our calculated $\delta^{18} \mathrm{O}_{\mathrm{sw}}$ record (Figure 4; see below for discussion) as well as from the dating of relict surfaces in the Antarctic Dry Valley region (see below for further discussion [Sugden and Denton, 2004; Lewis et al., 2006]).

\subsubsection{Ice Volume Estimates from $\delta^{18} \mathrm{O}_{\text {sw }}$}

[24] To calculate the $\delta^{18} \mathrm{O}$ of regional seawater $\left(\delta^{18} \mathrm{O}_{\mathrm{sw}}\right)$ from paired BWT (1 s.d.: $\left.\pm 1-3^{\circ} \mathrm{C}\right)$ and benthic foraminifer $\delta^{18} \mathrm{O}$ (1 s.d.: $\pm 0.1 \%$ [Shevenell and Kennett, 2004]) records, we used the $C$. pachyderma (C. mundulus) specific $\delta^{18} \mathrm{O}$ paleotemperature equation of Lynch-Stieglitz et al. [1999] combined with the BWTs derived from the Lear et al. [2003] equation:

$$
\delta^{18} \mathrm{O}_{\text {calcite }}(\mathrm{PDB})=\mathrm{d}^{18} \mathrm{O}_{\mathrm{sw}}(\mathrm{SMOW})-0.21 \mathrm{~T}+3.38-0.27
$$

Results reveal that $0.82 \pm 0.43 \%$ o $(\sim 70 \%)$ of the $1.2 \%$ Cibicidoides mundulus $\delta^{18} \mathrm{O}$ increase between 14.1 and 13.7 Ma relates to Antarctic ice growth and $\sim 30 \%$ relates to cooling (Figure 3). Comparison of the Site $1171 \delta^{18} \mathrm{O}_{\mathrm{sw}}$ curve with lower resolution records of Lear et al. [2000] and Billups and Schrag [2002, 2003] suggests similarities between the three records $\left(\delta^{18} \mathrm{O}_{\mathrm{sw}}:-0.5-1 \%\right)$ and confirms at highresolution previous indirect or lower resolution ice volume estimates [Shackleton and Kennett, 1975; Wright et al., 1992; Lear et al., 2000; Billups and Schrag, 2002, 2003; John et al., 2004]. Thus $\delta^{18} \mathrm{O}_{\mathrm{sw}}$ results from Site 1171 likely reflect global ice volume and not just regional changes in $\delta^{18} \mathrm{O}_{\mathrm{sw}}$.

[25] The calculated $\delta^{18} \mathrm{O}_{\mathrm{sw}}$ record from Site 1171 provides novel high-resolution insight into the phasing of ice growth and Southern Ocean temperatures in the Southwest Pacific during the middle Miocene climate transition not available from the previous lower resolution $\mathrm{Mg} / \mathrm{Ca}$ records of Lear et al. [2000] and Billups and Schrag [2002]. A general trend toward more positive $\delta^{18} \mathrm{O}_{\mathrm{sw}}$ values between 15 and 13.8 Ma (Figure 3) at Site 1171 suggests that Antarctic cryosphere expansion began at the height of the warm Miocene Climatic Optimum ( $\sim 15 \mathrm{Ma}$ [Shevenell et al., 2004]) and this expansion progressed in a stepwise fashion until 13.8 Ma (Figures 2 and 3). Three intervals of more positive and variable $\delta^{18} \mathrm{O}_{\mathrm{sw}}$ values are superimposed on the general trend and interpreted as intervals of glacial advance (midpoints: 14.9, 14.4, and $13.8 \mathrm{Ma}$ ). These glacial advances are generally associated with warmer surface and bottom water temperatures in the South Tasman Rise region (Figure 4). Three intervals of more negative $\delta^{18} \mathrm{O}_{\mathrm{sw}}$ values occur at $15.0,14.7$, and $14.0 \mathrm{Ma}$ and are interpreted as times of glacial retreat. These interglacials are associated with times of cooler surface and bottom water temperatures at Site 1171 (Figure 4). Interestingly, the final interglacial prior to the middle Miocene $\delta^{18} \mathrm{O}$ increase is associated with a stepwise cooling of South Tasman Rise surface waters interpreted to reflect an increase in the strength and/or northward progression of the 
Antarctic Circumpolar Current in the Southwest Pacific (Figure 4 [Shevenell et al., 2004]), as well as with the $2 \pm 2^{\circ} \mathrm{C}$ cooling of regional bottom waters (Figure 4).

[26] The $\delta^{18} \mathrm{O}_{\mathrm{sw}}$ record from Site 1171 indicates that the Antarctic cryosphere underwent a phase of rapid, seemingly orbitally paced ice growth between 15 and $\sim 14 \mathrm{Ma}$. The inferred glacial-interglacial cycles in the $\delta^{18} \mathrm{O}_{\mathrm{sw}}$ record (Figure 4) recur every $\sim 400$-ka, suggesting eccentricity pacing of the Middle Miocene Antarctic cryosphere expansion. Similar pacing is observed in global middle Miocene benthic foraminifer $\delta^{13} \mathrm{C}$ records of the Monterey interval (17-13.5 Ma [Vincent and Berger, 1985; Woodruff and Savin, 1989; Flower and Kennett, 1994; Holbourn et al., 2007]). Such a strong long-period eccentricity signal suggests a central role for internal climate system feedbacks (e.g., ice/albedo, global carbon cycling, ocean circulation changes) in this major Cenozoic climate transition [Shackleton, 2000]. The apparent increase in the intensity of Antarctic glaciations approaching $\sim 14 \mathrm{Ma}$ provides further evidence for such internal climate system feedbacks.

[27] Our interpretation of the $\delta^{18} \mathrm{O}_{\mathrm{sw}}$ record from Site 1171 as a proxy record for changes in ice volume is consistent with terrestrial and marine geologic records from Antarctica and its continental margins, which indicate that expansion of Antarctic ice sheets began at $\sim 15 \mathrm{Ma}$. Radiogenic isotope records from the circum-Antarctic indicate a shift towards more physical weathering of Antarctica at $\sim 15$ Ma [Vlastelic et al., 2005] while exposure dating of relict surfaces in the Antarctic Dry Valley region suggest an expansion of the ice sheet into the region at $14.8 \mathrm{Ma}$ and a retreat by 13.6 Ma [Sugden and Denton, 2004]. Furthermore, sequence stratigraphic records of eustasy in the middle Miocene [Haq et al., 1987; Miller et al., 1991b; Wright et al., 1992; John et al., 2004] indicate broad similarities to the calculated Site $1171 \delta^{18} \mathrm{O}_{\mathrm{sw}}$ curve, within current dating resolution of the records. However, none of these records are presently of sufficient orbital-scale resolution to be definitively compared to the calculated $\delta^{18} \mathrm{O}_{\mathrm{sw}}$ record from Site 1171. Ongoing sequence stratigraphic studies of the middle Miocene interval similar to those conducted across the Eocene/ Oligocene boundary [Kominz and Pekar, 2001] will likely yield accurate orbital scale records of changes in global eustasy that may be useful for comparison with our record [Miller et al., 2005; K. G. Miller et al., personal communication, 2006].

\subsubsection{Importance of Moisture Supply in Middle Miocene Antarctic Ice Sheet Expansion}

[28] Southern Ocean temperatures and seawater $\delta^{18} \mathrm{O}$ estimates reveal substantial Antarctic ice growth began during the warm Miocene Climatic Optimum ( $\sim 15 \mathrm{Ma})$ (Figure 4 [Shevenell et al., 2004]) when Southwest Pacific bottom water and sea surface temperatures were relatively warm. The Site 1171 benthic $\mathrm{Mg} / \mathrm{Ca}$ record confirms, at higher resolution, the $\mathrm{Mg} / \mathrm{Ca}$ findings of Lear et al. [2000] and Billups and Schrag [2000] and other more indirect estimates (Shackleton and Kennett [1975], Wright et al. [1992], John et al. [2004], and others) which suggest that the majority of the middle Miocene $\delta^{18} \mathrm{O}$ increase at $\sim 14 \mathrm{Ma}$ was related to an increase in global ice volume. Our records are especially significant in that they suggest that ice growth began during the warmest period of the Neogene (the Miocene Climatic Optimum at $\sim 15 \mathrm{Ma}), \sim 1 \mathrm{Ma}$ prior to the globally recognized climate step during a time of inferred low atmospheric $p \mathrm{CO}_{2}$ (Vincent and Berger [1985], Pagani et al. [1999], and others), and progressed in a stepwise orbitally paced fashion between $\sim 15$ and $14 \mathrm{Ma}$. This pattern of glaciation is further supported by lower latitude benthic foraminifer $\delta^{18} \mathrm{O}$ records from the subtropical Pacific, which show orbitally paced changes inferred as glacialinterglacial cycles between 14.7 and $13.8 \mathrm{Ma}$ [Holbourn et al., 2005]. On orbital timescales, our records suggest that Antarctic ice growth appears to coincide with times when Southern Ocean temperatures were particularly warm (Figure 4). The observed relationship (both the long-term trend and on orbital scales) between Southwest Pacific temperature and inferred ice growth challenges the notion that meridional heat flux limited Antarctic ice growth [Woodruff and Savin, 1989] and instead provides support for hypotheses positing that poleward heat/moisture supply was essential for Antarctic cryosphere expansion [Schnitker, 1980; Prentice and Matthews, 1991]. It remains unclear as to the origin of this heat/moisture (e.g. Warm Saline Deep Water from the Tethys, proto-North Atlantic Deep Water, or surface/atmospheric sources).

[29] The importance of moisture availability to the development and maintenance of Antarctic ice sheets is highlighted in terrestrial records from the Antarctic Dry Valleys (Ross Sea sector) (Sugden and Denton [2004] and others). Presently, the majority of Antarctica's precipitation is concentrated in 
the coastal regions. However, several coastal locations, including the Dry Valleys, appear to have remained predominantly ice-free since $\sim 13.6 \mathrm{Ma}$ due to limited regional moisture availability [Sugden and Denton, 2004]. This inferred long-term environmental stability suggests that middle Miocene Antarctic cryosphere expansion altered regional heat/ moisture supply [Sugden and Denton, 2004] and/or the Antarctica's sensitivity to mid- to low-latitude derived heat/moisture [DeConto and Pollard, 2003]. Geomorphology of the Dry Valleys indicates that relatively humid conditions prevailed at $\sim 15 \mathrm{Ma}$ and that the East Antarctic Ice Sheet inundated the region by $14.8 \mathrm{Ma}$ and retreated by $\sim 13.6 \mathrm{Ma}$ [Marchant et al., 1993; Sugden and Denton, 2004]. The timing of this inferred glacial expansion and retreat corresponds with our marine geochemical evidence (Figure 4), providing independent support for our interpretation of $\delta^{18} \mathrm{O}_{\mathrm{sw}}$ as a record of Antarctic ice growth and for changes in moisture flux to the region at the end of the Miocene Climatic Optimum.

[30] Intensified oceanic and atmospheric circulation capable of altering the flux of low-latitudederived heat/moisture to the Southern Ocean is inferred during the middle Miocene [Kennett et al., 1985; Vincent and Berger, 1985; Woodruff and Savin, 1989; Flower and Kennett, 1994; Shevenell et al., 2004]. A progressive orbitally paced increase in Antarctic Circumpolar Current strength between 14.2 and $13.8 \mathrm{Ma}$, inferred from the stepwise cooling of regional surface waters [Shevenell et al., 2004], could have isolated Antarctica from low-latitude heat/moisture sources and acted as a negative feedback towards further ice growth. Alternatively, the progressive reduction of warm low-latitude-derived deep-water associated with the tectonic restriction of the eastern Tethys may have removed an oceanic heat source from the Southern Ocean [Hsu and Bernoulli, 1978; Woodruff and Savin, 1989; Flower and Kennett, 1994]. Although the origin and transport mode (atmosphere or ocean) of Southern Ocean heat remain unconstrained, evidence suggests that the continued isolation of Antarctica (via tectonics and circulation) was critical to the progressive Cenozoic development of the Antarctic cryosphere.

\subsubsection{Is There a Role for $\mathrm{pCO}_{2}$ in Middle Miocene Antarctic Cryosphere Expansion?}

[31] Antarctica may have been poised to respond sensitively to poleward heat/moisture transport in the middle Miocene due to relatively low inferred atmospheric $p \mathrm{CO}_{2}$ (220-250 ppmv; Vincent and Berger [1985], Pagani et al. [1999], Pearson and
Palmer [2000], DeConto and Pollard [2003], and others). Model results suggest that under declining $p \mathrm{CO}_{2}$ and other greenhouse gases (e.g., $\mathrm{CH}_{4}$ ), Antarctic snowline elevations would have dropped, increasing the area of Antarctica available for glaciation [DeConto and Pollard, 2003]. Our high-resolution geochemical records from the Southwest Pacific suggest that Antarctic cryosphere expansion began in earnest at $\sim 15 \mathrm{Ma}$ (Figures 2 and 3), when atmospheric $p \mathrm{CO}_{2}$ levels reached the lowest inferred levels of the Miocene [Pagani et al., 1999; Pearson and Palmer, 2000] and regional Southern Ocean temperatures were relatively warm (Figure 4 [Shevenell et al., 2004]). Thus Site 1171 geochemical records provide support for models suggesting that the Antarctic cryosphere may be especially sensitive to poleward heat/moisture flux under low $p \mathrm{CO}_{2}$ boundary conditions [DeConto and Pollard, 2003]. In the early stages of middle Miocene ice expansion ( 15 Ma), warm Southern Ocean waters may have supplied heat/moisture to the Antarctic continent (Figure 4). As glaciation progressed, internal climate feedbacks (e.g., invigorated circumpolar circulation, ice/albedo) likely further isolated Antarctica from lower latitude derived heat/moisture. The stepwise character of the $\delta^{18} \mathrm{O}_{\mathrm{sw}}$ (ice volume) record and the Mg-derived SST records (Figure 4 [Shevenell et al., 2004]) support this interpretation. By $\sim 13.5 \mathrm{Ma}$, Antarctic cryosphere expansion had slowed/ceased, Southern Ocean temperatures cooled, and higher threshold $p \mathrm{CO}_{2}$ levels are inferred (Figures 2 and 3 [Pagani et al., 1999; Shevenell et al., 2004]).

[32] Not only did Antarctica's sensitivity to poleward heat/moisture flux appear to decrease with rising atmospheric $p \mathrm{CO}_{2}$ [DeConto and Pollard, 2003; Sugden and Denton, 2004], but that the expansion of Antarctic ice sheets likely exerted influence on the global carbon cycle in a similar fashion to that observed following both the Oi-1 and Mi-1 glaciations [Lear et al., 2004]. We speculate that this control resulted in both the final and largest marine $\delta^{13} \mathrm{C}$ increase (CM6) of the "Monterey interval" at 13.7 Ma (Flower and Kennett [1994] and others) as well as the decline in marine carbonate $\delta^{13} \mathrm{C}$ at $13.5 \mathrm{Ma}$ that marked the end "Monterey" interval (16.5-13.5 Ma [Vincent and Berger, 1985]) and a shift in global carbon cycle dynamics.

\section{Conclusions}

[33] Results demonstrate that Southern Ocean BWTs south of Tasmania (ODP Site 1171) did not cool significantly $\left(\sim 2 \pm 2^{\circ} \mathrm{C}\right)$ or permanently in 
association with the middle Miocene global $\delta^{18} \mathrm{O}$ increaseor perninantly in, suggesting that $\sim 70 \%$ of the global benthic foraminifer $\delta^{18} \mathrm{O}$ increase at $\sim 14$ Ma relates to Antarctic cryosphere expansion. This result confirms at high-resolution previous low-resolution benthic foraminifer $\mathrm{Mg} / \mathrm{Ca}$ results and less direct ice volume estimates from the middle Miocene [Flower and Kennett, 1994; Lear et al., 2000; John et al., 2004; Billups and Schrag, 2002], suggesting that the Site 1171 benthic foraminifer $\mathrm{Mg} / \mathrm{Ca}$ record is of global and not just regional significance. Furthermore, the lack of bottom water cooling across the middle Miocene $\delta^{18} \mathrm{O}$ increase is similar to patterns observed across both the Oi-1 and Mi-1 glaciations [Lear et al., 2000, 2004], suggesting similar climate forcings were involved. Our new high-resolution benthic foraminifer $\mathrm{Mg} / \mathrm{Ca}$ and calculated $\delta^{18} \mathrm{O}_{\mathrm{sw}}$ (ice volume) records reveal eccentricity-paced ( $\sim 400 \mathrm{ka})$ cryosphere expansion between 15 and $13.8 \mathrm{Ma}$ (Figure 3) occurred during an interval of relatively warm Southern Ocean waters at the height of the Miocene Climatic Optimum [Shevenell et al., 2004], when atmospheric $p \mathrm{CO}_{2}$ is inferred to have been relatively low [Pagani et al., 1999].

[34] The benthic $\mathrm{Mg} / \mathrm{Ca}$ data suggest that the Antarctic cryosphere may have been particularly sensitive to changes in poleward heat/moisture transport and insolation during the Middle Miocene [Pagani et al., 1999; DeConto and Pollard, 2003]. Invigorated oceanic/atmospheric circulation associated with internal climate feedbacks (e.g., ice/albedo feedbacks) between 14.2 and $13.8 \mathrm{Ma}$ [Shevenell et al., 2004] likely acted to further isolate Antarctica from low-latitude heat/moisture sources. This isolation, coupled with an inferred increase in atmospheric $p \mathrm{CO}_{2}$ [Pagani et al., 1999], reduced the sensitivity of Antarctica to lower latitude-derived heat/moisture and facilitated the transition of Earth's climate system to a new, relatively stable glacial state. Future research efforts should focus on determining the source of regional heat (e.g., oceanic or atmospheric) and the causes of the warmth during the Miocene Climatic Optimum and the factors influencing atmospheric $p \mathrm{CO}_{2}$ in the early to middle Miocene.

\section{Acknowledgments}

[35] We thank A. Tudhope and S. Emerson for comments on previous manuscript versions, K. Thompson, G. Paradis, and H. Berg for technical assistance, the Ocean Drilling Program for sampling assistance, and the ODP Leg 189 Shipboard Scientific Party. We thank two anonymous reviewers for their careful reviews that substantially improved the quality and accuracy of this submission. Research was supported by National Science Foundation (OPP-0229898) and JOI/USSSP grants to J. P. Kennett and A. E. Shevenell.

\section{References}

Anderson, J. B. (1999), Antarctic Marine Geology, p. 289, Cambridge Univ. Press, Cambridge, U. K.

Billups, K., and D. P. Schrag (2002), Paleotemperatures and ice volume of the past $27 \mathrm{Myr}$ revisited with paired $\mathrm{Mg} / \mathrm{Ca}$ and ${ }^{18} \mathrm{O} /{ }^{16} \mathrm{O}$ measurements on benthic foraminifera, Paleoceanography, 17(1), 1003, doi:10.1029/2000PA000567.

Billups, K., and D. P. Schrag (2003), Application of benthic foraminiferal $\mathrm{Mg} / \mathrm{Ca}$ ratios to questions of Cenozoic climate change, Earth. Planet. Sci. Lett., 209, 181-195.

Boyle, E. A., and L. D. Keigwin (1985), Comparison of Atlantic and Pacific paleochemical records for the last 215,000 years: Changes in deep ocean circulation and chemical inventories, Earth Planet. Sci. Lett., 76, 135-150.

Broecker, W. S., and T.-H. Peng (1982), Tracers in the Sea, Lamont-Doherty Earth Obs., Palisades, N. Y.

Cape Roberts Science Team (2000), Summary of results, in Studies from Cape Roberts Project: Initial Report on CRP-3, Ross Sea, Antarctica, edited by P. J. Barrett, M. Sarti, and S. Wise, Terra Antarct., 8, 185-203.

DeConto, R. M., and D. Pollard (2003), Rapid Cenozoic glaciation of Antarctica induced by declining atmospheric $\mathrm{CO}_{2}$, Nature, 421, 245-249.

Elderfield, H., J. Yu, P. Anand, T. Kiefer, and B. Nyland (2006), Calibrations for benthic foraminiferal $\mathrm{Mg} / \mathrm{Ca}$ paleothermometry and the carbonate ion hypothesis, Earth Planet. Sci. Lett., 250, 633-649.

Exon, N. F., J. P. Kennett, M. J. Malone, and the Leg 189 Shipboard Scientific Party (2001), Proceedings of Ocean Drilling Program Initial Report [CD-ROM], vol. 189, Ocean Drill. Program, College Station, Tex.

Flower, B. P., and J. P. Kennett (1994), The middle Miocene climate transition: East Antarctic ice sheet development, deep ocean circulation and global carbon cycling, Palaeogeogr. Palaeoclimatol. Palaeoecol., 108, 537-555.

Haq, B. U., J. Hardenbol, and P. R. Vail (1987), Chronology of fluctuating sea levels since the Triassic, Science, 235, 11561167.

Holbourn, A., W. Kuhnt, M. Schulz, and H. Erlenkeuser (2005), Impacts of orbital forcing and atmospheric carbon dioxide on Miocene ice-sheet expansion, Nature, 438, $483-$ 487.

Holbourn, A., W. Kuhnt, M. Schulz, J.-A. Flores, and N. Andersen (2007), Orbitally paced climate evolution during the middle Miocene "Monterey" carbon isotope excursion, Earth Planet Sci. Lett., 261, 534-550.

Hsu, K. J., and D. Bernoulli (1978), Genesis of the Tethys and the Mediterranean, Initial Rep. Deep Sea Drill. Proj., 42, 943-950.

John, C. M., G. D. Karner, and M. Muiti (2004), $\delta^{18} \mathrm{O}$ and Marion Plateau backstripping: Combining two approaches to constrain late middle Miocene eustatic amplitude, Geology, $32,829-832$

Kennett, J. P., and P. F. Barker (1990), Latest Cretaceous to Cenozoic climate and oceanographic developments in the Weddell Sea, Antarctic: An ocean-drilling perspective, Proc. Ocean Drill. Program Sci. Res., 113, 937-960.

Kennett, J. P., G. Keller, and M. S. Srinivasan (1985), Miocene planktonic foraminiferal biogeography and paleoceanographic development of the Indo-Pacific region, in The Mio- 
cene Ocean: Paleoceanography and Biogeography, edited by J. P. Kennett, Geol. Soc. Am. Mem., 163, 197-236.

Kominz, M. A., and S. F. Pekar (2001), Oligocene eustasy from two-dimensional sequence stratigraphic backstripping, Geol. Soc. Am. Bull., 113, 291-301.

Lawver, L. A., L. M. Gahagan, and M. F. Coffin (1992), The development of paleoseaways around Antarctica, in The Antarctic Paleoenvironment: A Perspective on Global Change, Part One, Ant. Res. Ser., vol. 56, edited by J. P. Kennett and D. A. Warnke pp. 7-30, AGU, Washington, D. C.

Lea, D. W. (2004), Elemental and isotopic proxies of past ocean temperatures, in The Oceans and Marine Chemistry, Treatise on Geochem., vol. 6, edited by H. Elderfield, pp. 365-390, Elsevier, New York.

Lea, D. W., and E. A. Boyle (1993), Determination of carbonate-bound barium in corals and foraminifer by isotope dilution plasma mass spectrometry, Chem. Geol., 103, 73-84.

Lea, D. W., and P. A. Martin (1996), A rapid mass spectrometric method for the simultaneous analysis of barium, cadmium, and strontium in foraminifera shells, Geochim. Cosmochim. Acta, 60, 3143-3149.

Lea, D. W., D. K. Pak, and H. J. Spero (2000), Climate impact of Late Quaternary equatorial Pacific sea surface temperature variations, Science, 289, 1719-1724.

Lear, C. H., H. Elderfield, and P. A. Wilson (2000), Cenozoic deep-sea temperatures and global ice volumes from $\mathrm{Mg} / \mathrm{Ca}$ in benthic foraminiferal calcite, Science, 287, 269-272.

Lear, C. H., Y. Rosenthal, and N. Slowey (2002), Benthic foraminiferal $\mathrm{Mg} / \mathrm{Ca}$-paleothermometry: A revised core-top calibration, Geochim. Cosmochim, Acta, 66, 3375-3387.

Lear, C. H., Y. Rosenthal, and J. D. Wright (2003), The closing of a seaway: Ocean water masses and global climate change, Earth Planet. Sci. Lett., 210, 425-436.

Lear, C. H., Y. Rosenthal, H. K. Coxall, and P. A. Wilson (2004), Late Eocene to early Miocene ice sheet dynamics and the global carbon cycle, Paleoceanography, 19, PA4015, doi:10.1029/2004PA001039.

Lewis, A. R., D. R. Marchant, D. E. Kowalewski, S. L. Baldwin, and L. E. Webb (2006), The age and origin of the Labyrinth, western Dry Valleys, Antarctica: Evidence for extensive middle Miocene subglacial floods and freshwater discharge to the Southern Ocean, Geology, 37, 513-516.

Lourens, L. J., F. J. Hilgen, J. Laskar, N. J. Shackleton, and D. Wilson (2004), The Neogene period, in Geologic Time Scale 2004, edited by F. Gradstein, J. Ogg, and A. Smith, pp. 409-440, Cambridge Univ. Press, New York.

Lynch-Stieglitz, J., W. B. Curry, and N. Slowey (1999), A geostrophic transport estimate for the Florida Current from the oxygen isotope composition of benthic foraminifera, Paleoceanography, 14, 360-373.

Marchant, D. R., G. H. Denton, and D. E. Sugden (1993), Miocene glacial stratigraphy and landscape evolution of the western Asgard Range, Geogr. Ann., 75A, 718-730.

Marchitto, T. M., S. P. Bryan, W. B. Curry, and D. C. McCorkle (2007), Mg/Ca temperature calibration for the benthic foraminifer Cibicidoides pachyderma, Paleoceanography, 22, PA1203, doi:10.1029/2006PA001287.

Margolis, S. V. (1975), Paleoglacial history of Antarctica inferred from analysis of Leg 29 sediments by scanning electron microscopy, Initial Rep. Deep Sea Drill. Proj., 29, $1039-1048$

Martin, P. A., D. W. Lea, Y. Rosenthal, N. J. Shackleton, M. Sarnthein, and T. Papenfuss (2002), Quaternary deep sea temperature histories derived from benthic foraminiferal $\mathrm{Mg}$ / Ca, Earth Planet. Sci. Lett., 198, 193-209.
Matthews, R. K., and R. Z. Poore (1980), Tertiary $\delta^{18} \mathrm{O}$ record and glacio-eustatic sea-level fluctuation, Geology, 8, 501504.

Miller, K. G., R. G. Fairbanks, and G. S. Mountain (1987), Tertiary oxygen isotope synthesis, sea level history, and continental margin erosion, Paleoceanography, 2, 1-19.

Miller, K. G., M. D. Feigenson, J. D. Wright, and B. M. Clement (1991a), Miocene isotope reference section, Deep Sea Drilling Project, Site 608: An evaluation of isotope and biostratigraphic resolution, Paleoceanography, 6, 33-52.

Miller, K. G., J. D. Wright, and R. G. Fairbanks (1991b), Unlocking the ice house: Oligocene-Miocene oxygen isotope, eustasy, and margin erosion, J. Geophys. Res., 69, 6829-6848.

Miller, K. G., M. A. Kominz, J. V. Browning, J. D. Wright, G. S. Mountain, M. E. Katz, P. J. Sugarman, B. S. Cramer, N. Christie-Blick, and S. J. Pekar (2005), The Phanerozoic record of global sea-level change, Science, 310, 1293-1298.

O’Neil, J. R., R. N. Clayton, and T. K. Mayeda (1969), Oxygen isotope fractionation in divalent metal carbonates, J. Chem. Phys., 5, 5547-5558.

Pagani, M., M. A. Arthur, and K. H. Freeman (1999), Miocene evolution of atmospheric carbon dioxide, Paleoceanography, 14, 273-292.

Pearson, P. N., and M. R. Palmer (2000), Atmospheric carbon dioxide concentrations over the past 60 million years, Nature, 406, 695-699.

Prentice, M. P., and R. K. Matthews (1991), Tertiary ice sheet dynamics: The snow gun hypothesis, J. Geophys. Res., 96, 6811-6827.

Rowley, D. B. (2002), Rate of plate creation and destruction: 180 Ma to present, Geol. Soc. Am, Bull., 114, 927-933.

Schnitker, D. (1980), North Atlantic oceanography as possible cause of Antarctic glaciation and eutrophication, Nature, $284,615-616$

Sclater, J. G., L. Meinke, A. Bennett, and C. Murphy (1985), The depth of the ocean through the Neogene, in The Miocene Ocean: Paleoceanography and Biogeography, edited by J. P. Kennett, Mem. Geol. Soc. Am., 163, 1-21

Shackleton, N. J. (2000), The 100000-year ice-age cycle identified and found to lag temperature, carbon dioxide, and orbital eccentricity, Science, 289, 1897-1902.

Shackleton, N. J., and J. P. Kennett (1975), Paleotemperature history of the Cenozoic and the initiation of Antarctic glaciation: Oxygen and carbon isotopic analyses in DSDP Sites 277, 279, and 281, Initial Rep. Deep Sea Drill. Proj., 29, $143-156$

Shackleton, N. J., and N. D. Opdyke (1973), Oxygen isotope and paleomagnetic stratigraphy of equatorial Pacific core V28-238: Oxygen isotope temperatures and ice volumes on a 105 and 106 year scale, Quat. Res., 3, 39-55.

Shevenell, A. E. (2004), The role of climate feedbacks in the Middle Miocene climate transition, Ph.D. dissertation, Univ. of Calif., Santa Barbara.

Shevenell, A. E., and J. P. Kennett (2004), Paleoceanographic change during the middle Miocene climate revolution: An Antarctic stable isotope perspective, in The Cenozoic Southern Ocean: Tectonics, Sedimentation, and Climate Change Between Australia and Antarctica, Geophys. Mon. Ser, vol. 151, edited by N. Exon, J. P. Kennett, and M. Malone, pp. 235-252, AGU, Washington, D. C.

Shevenell, A. E., J. P. Kennett, and D. W. Lea (2004), Middle Miocene Southern Ocean cooling and Antarctic cryosphere expansion, Science, 305, 1766-1770

Stanley, S. M., and L. M. Hardie (1998), Secular oscillations in the carbonate mineralogy of reef-building and sediment pro- 
ducing organisms driven by tectonically forced shifts in seawater chemistry, Palaeogeogr. Palaeoclimatol. Palaeoecol., $144,3-19$

Sugden, D., and G. Denton (2004), Cenozoic landscape evolution of the Convoy Range to Mackay Glacier area, Transantarctic Mountains: Onshore to offshore synthesis, Geol. Soc. Am. Bull., 116, 840-857.

Vincent, E., and W. H. Berger (1985), Carbon dioxide and polar cooling in the Miocene, in The Carbon Cycle and Atmospheric $\mathrm{CO}_{2}$ : Natural Variations Archean to Present, Geophys. Monogr. Ser., vol. 32, edited by E. T. Sundquist and W. S. Broecker, pp. 455-468, AGU, Washington, D. C.

Vlastelic, I., M. Carpentier, and E. Lewin (2005), Miocene climate change recorded in the chemical and isotopic $(\mathrm{Pb}$, $\mathrm{Nd}$, Hf) signature of Southern Ocean sediments, Geochem. Geophys. Geosyst., 6, Q03003, doi:10.1029/2004GC000819.

Wilkinson, B. H., and T. J. Algeo (1989), Sedimentary carbonate record of calcium-magnesium cycling, Am. J. Sci., 289, $1158-1194$.
Woodruff, F., and S. M. Savin (1989), Miocene deepwater oceanography, Paleoceanography, 4, 87-140.

Woodruff, F., and S. M. Savin (1991), Mid-Miocene isotope stratigraphy in the deep sea: high-resolution correlations, paleoclimatic cycles, and sediment preservation, Paleoceanography, 6, 755-806.

Wright, J. D., K. G. Miller, and R. G. Fairbanks (1992), Evolution of modern deepwater circulation: Evidence from the late Miocene Southern Ocean, Paleoceanography, 6, 275290.

Zachos, J. C., M. Pagani, L. C. Sloan, E. Thomas, and K. Billups (2001), Trends, rhythms, and aberrations in global climate $65 \mathrm{Ma}$ to present, Science, 292, 686-693.

Zachos, J. C., M. W. Wara, S. Bohaty, M. L. Delaney, M. R. Petrizzo, A. Brill, T. J. Bralower, and I. Premoli-Silva (2003), A transient rise in tropical sea surface temperature during the Paleocene-Eocene thermal maximum, Science, 302, 1551-1554. 